\title{
視覚センサのオフラインプログラミングを 支援するハンドアイシミュレータ†
}

\author{
坂 根 茂 幸*.石 井 優* ・柿 倉 正 義* \\ Hand-Eye Simulator for Off-Line Programming of Visual Sensors
}

Shigeyuki SAKanE*, Masaru IshII* and Masayoshi KakIKuRA*

\begin{abstract}
Model-based approaches are essential to the development of robots with high adaptability to various environments. We propose the concept of a Hand-eye simulator: a simulator for a hand-eye coordinating system as a basic tool for off-line programming of visual sensors. The simulator provides useful functions to assist the hand-eye coordinating system in visual recognition and monitoring of the robot environment. Two of these functions, one for eliminating the appearance of the manipulator from the input images to reduce unnecessary image features and another for assisting cameras in occlusion avoidance to get adequate image data without occlusion are described. Solving the problems in effective use of multiple and various kinds of sensors, based on the simulators as described in this paper, will become a key issue for making intelligent hand-eye coordinating systems.
\end{abstract}

Key Words : robot simulator, hand-eye coordinating system, 3D modeling, model-based robot vision, sensor strategy, robot programming

\section{1. まえがき}

従来のティーチングに代るロボット言語を用いたロ ボットの教示システム,すなわち,オフラインプログラ ミングのシステムでは，実際のロボットを動かさずに プログラム作成を行うので，作成したプログラムによ るロボットの動作確認をするためのシミュレータが必 要になる.ロボットシミュレータでは, 単に機構動作 を模擬して表示する機能以外にあ，マニピュレータの 動的特性や環境条件を含む物理的な特性のシミュレー

†第 24 回計測自動制御学会学術講演会で発表 (昭 $60 \cdot 7)$

* 電子技術総合研究所 茨城県新治郡桜村梅園 1-1-4

* Electrotechnical Laboratory, Niihari-gun, Ibaraki (Received August 6, 1985)
ション等へあ拡張できるととが望ましい. マニピュレ 一タが環境内にある物体と衝突を起とさないかどうか を調べる干渉チェック機能などが，その例である：乙 のようなシミュレータ機能の高度化に伴なうロボット 環境モデル管理機能の拡大は, 必然的に“作業レベル” のロボット言語によるプログラミングの基礎技術を形 成する.

一方，ロボットが環境に対する適応性・柔軟性を高 めるためには, 各種のロボットセンサの利用, 中であ 視覚センサの利用が重要である.そして，マニピュレ 一タに抢けるロボットシミュレータの利用と同様に, 視覚センサに拈いてあそのシミュレータの利用が考え られる. 従来, ハンドリング対象物を含めた認識のた めの環境の 3 次元モデルの構成と利用という側面では 多くの試みが行われているが，乙れらあロボットの視 覚のためのシミュレータ機能のカテゴリに含めること ができる. ロボットの自律機能を高めていく上では， てれ以外にあ, 視覚センサの効果的な運用を図るため のシミュレータの開発が重要な課題である.しかしな がら，これらに関する研究は，まだ殆ど行われていな い.

本論文では, ハンドアイシステムにおける視覚セン サのオフラインプログラミングを支援するためのロボ ットシミュレータの概念を提案する，つぎに，実際の ハンドアイシステムに即して開発したシミニレータシ ステムの基本的構成と, その特徵的機能である視野内 マニピュレータ像の消去機能, および, オクルージョ ン回避の支援機能について述べる.

\section{2. 視覚センサとロボットシミュレータ}

ロボットセンサは，一般に，作業あるいは環境内の 不確定な要素に対処するために用いられる. その果す 主な役割には， 
（1）ロボット動作の起動と停止

（2）選択可能な行動がある場合の行動決定

（3）対象物の同定之位置決め

（4）外部の拘束に対する適応

がある”。、ロボットの視覚では，この中の（3)の課題 について多くの研究と実用化が進められている。これ に関連するロボットシミュレータの課題には，認識す べき対象物のモデルの構成と利用がある.対象物の同 定などを行うロボット視覚装置が市販されているが, これらの装置の大部分は, 同定する対象物のモデルの 教示のために実物を提示し，画像処理により特徵パラ メータを求めて認識アルゴリズムにおけるモデルとす る方式を採用している。しかし，てのような実例によ る教示方式と 2 次元の画像特徴に基づく認識方式には 限界があり, 高度化するロボット作業に要求される視 覚機能には，対象の 3 次元モデルの利用が本質的に必 要となる22.

一方, 視覚センサの $(2)$ の課題に関しては, 例え ば, 視点が移動可能であったり, 多種類, 複数個の視 覚センサが利用可能な場合に，どのような状況でどの センサを用いるべきがんう計画を決定していくこと が必要になる，乙の場合において屯，（3）の場合と同 様に, ロボットの環境の 3 次元モデルに基づいた視覚 センサ用シミュレータの構成が重要な役割を果す．と のようなシミュレータの開発は，ロボットビジョンの ための言語開発3),4)などと共に，今後，作業レベルの ロボットプログラミングを実現していくために必要不 可欠である ${ }^{5}$.

\section{3. ハンドアイシミュレータ}

\section{1 ハンドアイシミュレータの概念と基本的仕様}

Fig. 1 のように，モデルベーズドなハンドアイシ ステムは，マニピュレータを制御するための行動系, 環境を理解するための認識系，および，それらにロボ ットの世界モデルを与えるためのモデル系から構成さ れる. ハンドアイシミュレータは，乙のモデル系の中 で, マニピュレータ, 視覚系 (撮像カメラ, 照明, 距 離センサ等), そして作業対象物を含む作業環境の実 世界を動的にシミュレートする，とてでの『動的』と

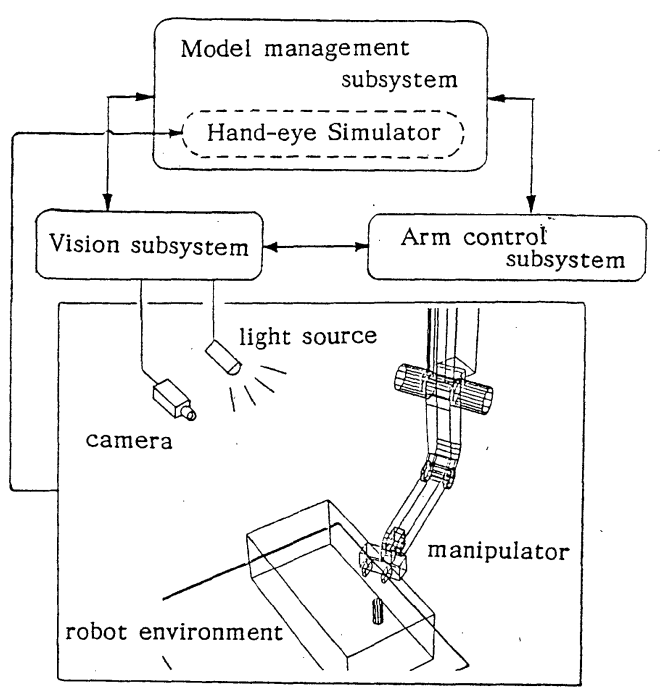

Fig. 1 Structure of a model-based hand-eye coordinating system

は，マニピュレータによる物体の操作で生じた環境の 変化が，モデルの世界であ並行して管理されていると いう意味である.

従来のロボットシミュレータは Table 1 中の*印 で示すように, 複数のマニピュレータ間, マニピュレ 一タと環境の間などの干渉問題を扱うあのであり, シ ミュレーションの課題として視覚系との関連について は特に関心が払われていなかった。また，ユーザの設 定するカメラあ，アームの動作のみを見るすのでしか ない，てれに対してハンドアイシミュレータでは，口 ボットの環境の認識・監視に使用するカメラがモデル 化されて㧍り，表の(1)，（2），（3)で示すように， ハンドアイシステムにおける視覚系とマニピュレー 夕, 視賞系と環境, および, 複数の視覚系の相互関係 の問題を取扱うことに特長がある.

(1)の視覚系とマニピュレータの関係では, 例え ば，マニピュレータを移動したときに，カメラの視野 のどの位置にその像が現れるかをシミュレートし，実 画像中のマニピュレータ像を消去して画像理解を援助 する. 乙の応用についで，第 4 章で述べる.

(2)では視覚系と環境の関係を扱う。例えば，ハン

Table 1 Relations of components in a hand-eye coordinating system and the subjects of the simulator

\begin{tabular}{c|c|c|c}
\hline manipulator & $\begin{array}{l}\text { robot } \\
\text { environment }\end{array}$ & vision devices & \\
\hline$*$ & $*$ & $(1)$ & manipulator \\
\hline & $*$ & $(2)$ & $\begin{array}{l}\text { robot } \\
\text { environment }\end{array}$ \\
\hline & & $(3)$ & vision devices \\
\hline
\end{tabular}


ド装着型カメラの場合には，すでにモデル化されてい る環境において, マニピュレータの移動に伴って変化 するカメラの視野モデルを生成しながら実環境の確認 を行うとと,また, 認識・監視に適した視点にマニピ ニレータを移動するためのシミニレーションなどへの 応用がある.この例として, 第 5 章では, オクルージ ョン回避の文援機能について述へる.

(3)では, 複数の視覚系間の関係を扱う。これに は，カメラと照明の関係をシミュレートすることや， 複数・多種類 (距離, 明暗等) の視覚センサをシミニ レートし，作業目的に合致した視覚系の総合的編成を 支援することなどが考えられる．

また，ハンドアイシミュレータと推論機能を結合す るととにより, 認識系にプラニング機能をあたせ，適 応性・柔軟性に富んだハンドアイシステムを構成する ことが可能になると思われる。

このようなハンドアイシミュレータを実現していく 上での必要となる基本的な機能をまとめると，つぎの ようになる。

(a) マニピュレータ, カメラ, 照明等の 3 次元位置・ 姿勢などの幾何学的モデリング機能

(b) 作業対象物を含むロボット環境の幾何学的モデリ ング機能

(C) カメラからの視野モデルの生成機能

(d) 生成した視野モデルに基づく, 実シーンとの照合 に必要な画像特徴の抽出機能

(e) 推論機能をむつプラニングシステムとの結合機能 これらの中で最も基本的なものは(b)(c)である.以

下 $3.2,3.3$ では, このインプリメンテーションの概 要を述へる。

\section{2 基礎部分のインプリメンテーション}

実際の対象としたハンドアイシステムのブロック構

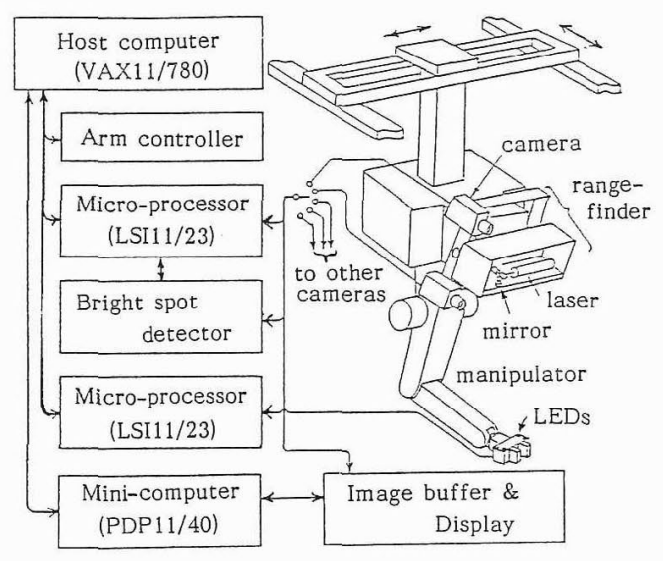

Fig. 2 Block-diagram of the hand-eye coordinating system
成図を Fig. 2 に, システムの外観を Photo. 1 亿示 す. 本システムでは，ホスト計算機 (VAX 11/780), ミニコン (PDP 11/40), マイクロプロセッサ (LSI 11/ 23）か，主な CPU である。 5 自由度けナームは, ホ スト計算機からコントローラを介して制御される，環 境の明暗画像入力には $2 \frac{1}{\text { a }}$ の固定型の CCD カメラ, および。ハンド部に装着可能な CCD カメラ (Photo. 2) が用いられる. 画像データは, A/D 変䍰されて画 像メモリに格納され， ホスト計算機に転送される 2 台の固定型力メラは, 明暗画像入力の他に, $\mathrm{He} \cdot \mathrm{Ne}$ レーザスポットの走査を行う1組のミラー系と共にレ ーザスポット方式のレンジファインダを構成し, 環境 の3 次元データ入力にす朋いられている．画面内の輝 点の 2 次元位㯰計測には，専用のハードゥェア（図中 の bright spot detector) 学使用している7.

ハンドアイシミニレータ定構築するための基本的な ツールとしては，3次元の幾何モデリングシステムで ある GEOMAP ${ }^{8}$ を利用している. 前述の仕様( ()を考 慮して, シミュレータの機能は LISP9) 上の関数で実行

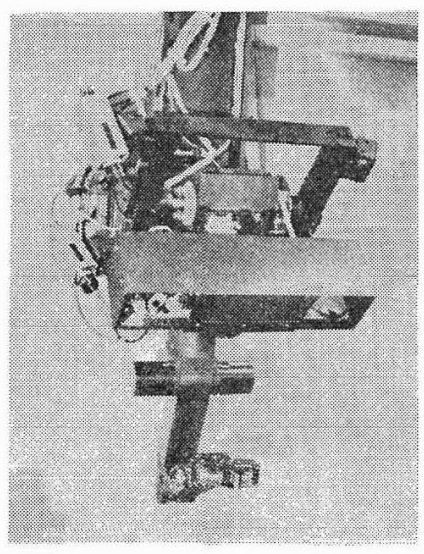

Photo. 1 Overview of the hand-eye coordinating system

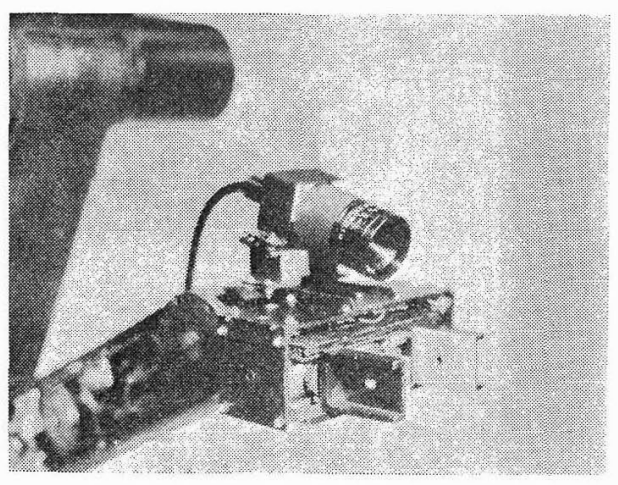

Photo. 2 A CCD camera mounted on the robot hand 


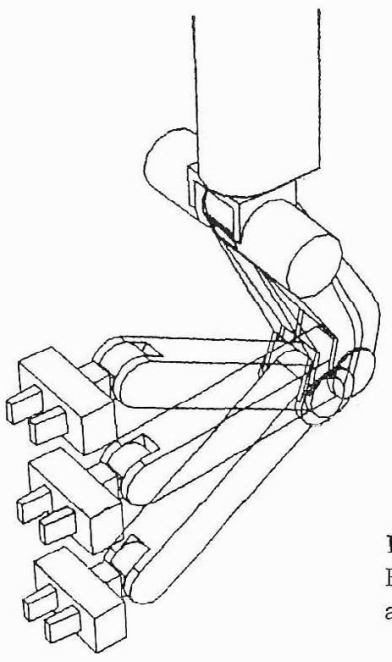

Fig. 3

Example movements of a manipulator model

ができるようになっている.マニピュレータの幾何モ デルは，実際のマニピュレータを駆動している動作レ ベルの言語10)により全く同様に駆動できる、例えば，

(ARM 'MVC-DIR '( $X Y Y Z \quad Z \alpha \beta \gamma)$ ) などの (ARM…) という形式の一連のマニピュレータ 制御用関数は，あらかじる (V-ARM-ON) を実行して おけばシミュレータのマニピュレータモデルを駆動 し，また，(R-ARM-ON) を実行しておけば，实際の マニピュレータを駆動するプログラムとなる．Fig. 3 に, マニピニレータモデルの動作例を示す.

撮像カメラをモデル化する透視变換のパラメータ は，カメラの光学中心位置 $\left(X_{C}, Y_{C}, Z_{C}\right)$, 画像面の回 転角 $\left(A_{x}, A_{y}, A_{z}\right)$ ， スケール変換係数 $\mathrm{F} の 7$ 個であ る。とれらのパラメータは，ハンドに取付けた LED (赤外発光素子) を用いたキャリブレーションにより マニピュレータ座標系で得られる。すなわち，LED の 3 次元位置とカメラ 画面上での 2 次元位置加ら，

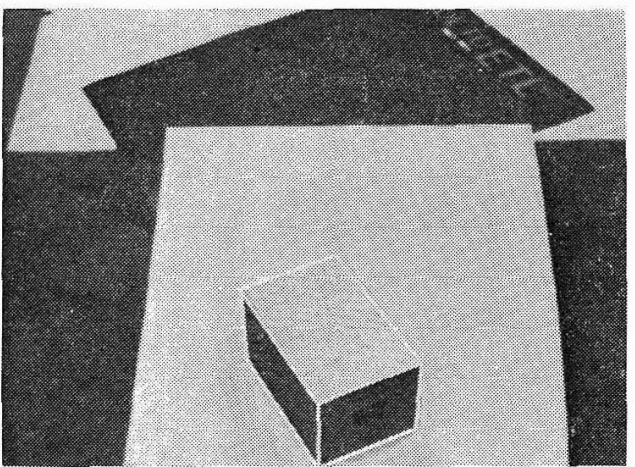

(a) Superimposed display of an object and the model at initial camera position
Newton 法を用いた計算 ${ }^{11)}$ ，または非反復解法 ${ }^{12)}$ を用 いてカメラパラメータを求るる. ハンド装着型のカメ ラのモデル化機能について，以下にその概略を述べ る.

\section{3 ハンド装着型カメラのモデル化}

ハンド装着型のカメラを用いるハンドアイシステム のシミュレータでは，このカメラモデルのパラメータ あマニピュレータ座標系で求める必要がある．とのた めに，すでにマニピュレータ座標系でのパラメータを 求めてある 2 台のカメラにより，キャリブレーション 用の可動板上に装着した発光素子に上る輝点の 3 次元 位置を求め, 同時にとの輝点をハンド装着型カメラで 観測する. このデータによりカメラモデルのパラメー 夕を推定する．このときのマニピュレータの位置・姿 勢の状態で，生成したカメラモデルをハンドのモデル に幾何学的に接続する. また，マニピュレータモデル の移動に伴い,カメラモデルのパラメータを自動的に 更新する機能をすたせている，したがって，作業環境 の3 次元モデルが得られていれば，マニピュレータの 移動に伴い変化する視野のモデルを生成できる.この 機能を確認するために，直方体の 3 次元モデルを用い た基䃈実験を行った。

最初の直方体の 3 次元モデル生成には, 前述のレー ザースポット光方式のレンジファインダを用いたイン タラクティブな教示方法を用いた. Photo. 3(a) は, 最初のマニピニレータの位置で撮像した実画像と生成 モデルとをスーパーインポーズした画像である.

Photo. 3(b)は，別の位置にマニピュレータを移動 したときの実画像と生成モデルを示している、マニピ ニレータの移動に伴うカメラパラメータの自動的な更 新処理により，撮像した画像が变化しても，カメラモ デルに射影した 3 次元モデルは常に重なった状態を保

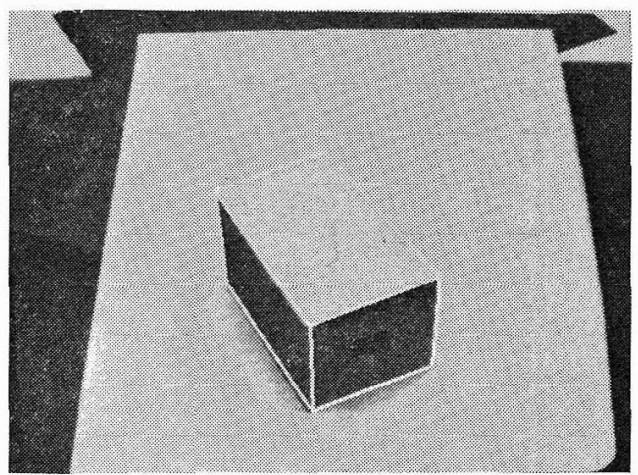

(b) The object and the model after moving the manipulator toward the object

Photo. 3 Example of view models generated by the camera-in-hand model 
っていることがわかる。

\section{4. 視野内マニピュレータ像の消去への適用}

\section{1 視野内マニピュレータ像問題}

視覚による認識では, 処理してむ無䭾な画像データ の処理は初めから行わず，注目したい部分の処理のみ を行う上うな効率的な機能が望まれる.

ハンドアイシステムの視覚では，その構成及び作業 の性質上，視野内にマニピュレータ像が現わ礼ること が多く, 対象の認識過程ではこの像む処理対象とな る. これを避けるためには，マニピュレータを視野外 に移動し，対象のみ撮像した画像を処理するのが $1 つ$ の対策である．しかし，てのようなマニピュレータの 動きは一般の作業にとってはて長であり，また場合に よっては円滑な作業の害行を纺げる。そこで本システ ムでは, ハンドアイシミュレータを用いて入力画像に 現れるマニピニレータ像を消去する機能を実現し，こ の問題定解決するための一手法とした，これは，ハン ドアイシミュレータにおいて，あらかじめ視野内のど

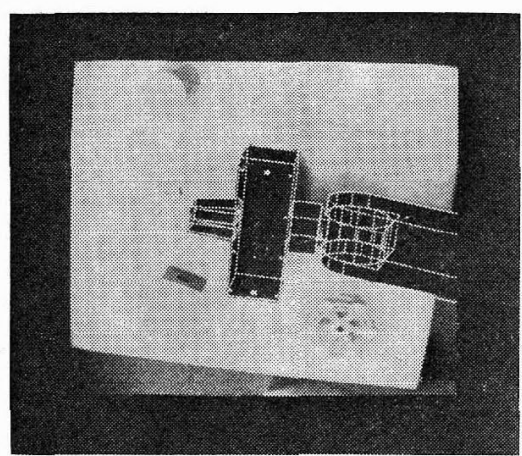

(a) Wire-frame model of the manipulator superimposed on the input image

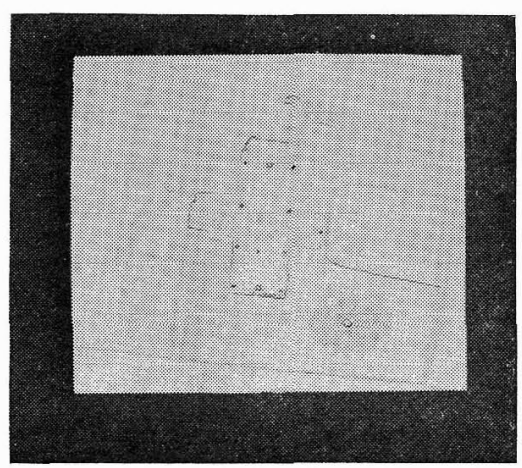

(c) Edge image of the input inage
の位置・姿勢にマニピュレータ像ができるかを求める ことができるという機能を利用したものである。

\section{2 視野内マニピュレータ像の消去}

視野内マニピュレータ像の消去処理の手順は，以下 のように実現している.

(1) 実マニピュレータとシミニレータを同時に駆動す る.

(2) 実マニピュレータを駆勳した後,シミュレータ側 では実際にシーンを撮像するカメラのモデルから見 えるモデルマニピュレータ像のシルエット 2 值画像 を生成する。

(3) モデルと奏画像の位置ずれの誤差を吸収するため に，この 2 值画像に膨張処理を施してマスク画像を 得る.

(4) 実画像又は前処理を行った画像に対してとのマス クをかけ，マニピュレータ像を消去する。

この中で，(2)の処理は，可視面に対してスキャンコン バージョンを行い，2 值画像配列上で塗りつぶしを行 う方法を採用している。また，(3における膨張好理と

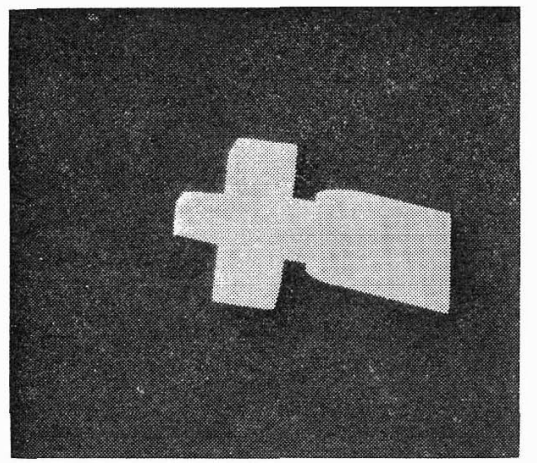

(b) Binary mask pattern of the manipulator by expansion processing

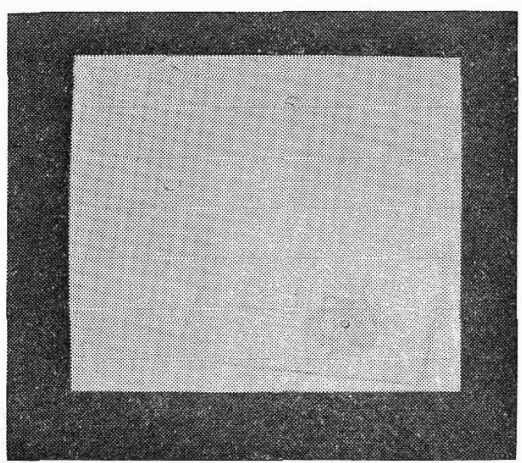

(d) The results of eliminating the manipulator in Photo (c) using the mask of (b)

Photo. 4 Experimental results of eliminating the manipulator from an input inaye 
は， $3 \times 3$ の局所領域で 8 連結（または 4 連結）の近 傍画素が一つでも值 1 を元で中心画素を 1 にする処 理である. (2)〜(4)の処理は, バードウェアによる高速 化が可能である.

\section{3 実 験}

Photo. 4(a)〜 (d) そ, 乙の実験例を示す. Photo. 4(a)は, 実マニピュレータとシミュレータのマニピ ユレータを共に初期位置から相対変位. ( $\Delta X, \Delta Y, \Delta Z)$ $=(300,0,200)(\mathrm{mm})$ の点に動かし，マニピュレータ像 を含むシーンを撮像した画像にシミュレータの線画出 力（隠線消去なし）を重称合せた結果である.ディジ タル画像の大きさは $512 \times 460$ である. シミュレータ 出力が実際のマニピュレータ位置と一致しているのが わかる. Photo. 4(b)は, マニピュレータモデルのシ ルエット 2 值画像に膨張処理を施した結果である. と こでは 8 連結近傍を用い, 処理を 5 回反復している. 本実験では，乙の程度の反復回数で位置ずれ誤差が允 分吸収されている. Photo. 4(c) は, 大力画像に対し て Sobel オペレータによる空間微分を行った結果で, マニピュレータ像も微分画像中に現われている．な お，エッジ画像を見易くするために，白黒は反転して いる. Photo. 4(d)は, Photo. 4( c)のエッジ画像に 対して Photo. 4(b)のマスク画像のマニピュレータ の領域の值を 0 とし, マニピュレータ像を消去した結 果である. これにより, 対象物の特徵抽出に処理を集 中するととが可能となり, 視覚センサのオフラインプ ログラミングとしての認識プログラムの作成も容易に なる、また，乙の例では，マニピュレータ像を消去し たが, この他にも，例えば，対象の認識・監視などに おいて, 画像情報としては必要のない固定治具などの 像についても, 同様な力法で消去するととができる.

\section{5. オクルージョン回避の支援機能}

\section{1 オクルージョン回避の概念}

ロボットが, カメラで撮像した画像に基づいてある 対象物を認識・監視するときに, 環境内の他物体やマ ニピュレータにより視野がさえぎられること（オクル ージョン) が生じる. このオクルージョンを避けるた めに，カメラが環境に固定される場合には初めから良 く見える位置に設置したり，また，カメラがハンドに 装着されている場合にはカメラを対象が良く見える位 置に移動したりする必要がある.このようなロボット の視覚系の合理的配置に関する概念を, “オクルーシ ヨン回避 (occlusion avodiance)” と呼ぶととにする. 従来のロボットシミュレータでは, マニピュレータと 環境内の物体との衝突を回避する軌道を決定する機能
の実現 ${ }^{13)}$ が一つの課題となるが，乙こで考えるオク ルージョン回避は視覚センサ系にとって丁度ての双対 概念に相当する. 従来とのような場合には, オペレー タが現場で実際の画面を見ながら，カメラの適切な位 置を定める必要があった. しかし，ハンドアイシミュ レータのモデリング機能に基づいたシステム構成によ り，ある注視対象を与えたときに他物体によるオクル ージョンを回避するカメラの位置を自動的に求めるこ とが可能となる.すなわち, 視覚センサのオフライン プログラミングを支援することができる.

オクルージョン回避問題には，見る対象（ここでは 『注視対象』と呼ぶ）の分類と得られる情報の種類に よるレベル分けが考えられる. 見たい注視対象は(1) 点, (2) 線, (3) 領域に分類される. また, 得られる 情報については，つぎの 2 レベルに分けられる.

（a）注視対象を環境の物体によりオクルージョンな しにカメラから見るととができるかを調べるオク ルージョン判定機能

（b）注視対象を与えるとオクルージョンが生じる. 3 次元空間内領域が求められ，乙の空間を回避して 適切なカメラの位置を決定する機能

この問題をマニピュレータの衝突回避問題に対応さ せると，（a）はアームと物体間の干渉チェック，（b） は自由空間記述に基づくアプローチに対応する.つま り,オクルージョンの生じない空間 (以下では, OFS : occiusion-free space と呼ぶ）の記述と利用が課題と なる. 問題の複雑さは, $(1)<(2)<(3)$, および, ( a $)<(b)$ の順である.

衝突回避問題では, ゴールとして手の移動地点が与 えられている. しかし, オクルージョン回避の場合に は，例えば，『ナットをボルト軸方向に対して斜めの 方向から，はめあい部分が良く見えるような距離で見 たい』というように複雑化し，ゴールの指定の仕方は 一般的に問題に依存する. このような点を考慮して, 現在までにハンドアイシミュレータに組み込んだ機能 は, 領域を注視対象としたオクルージョン判定の機能 と, 点を注視対象とした OFS の抽出機能である. 以 下に，とれらについて述べる.

\section{2 オクルージョン判定機能}

ハンドアイシミュレータに組み込んだオクルージョ ン判定 (occlusion check) 機能は, 以下のような処理 手順で実現している.

（1）注視領域を，カメラ画面上に射影して得られる 領域 R 1 の各点に括けるカメラ中心からの奥行值 を求める.

（2）オクルージョン物体を，カメラ画面上に射影し 
坂根・石井・柿倉：視覚センサのオフラインプログラミングを支援するハンドアイシミュレータ

て得られる領域 $\mathrm{R} 2$ の各点におりる奥行值を求め る.

（3）領域 $\mathrm{R} 1$ と R 2 の論理積領域 $\mathrm{R} 3=\mathrm{R} 1 \cap \mathrm{R} 2$ を 求めて, この領域内の各点における $\mathrm{R} 1$ と $\mathrm{R} 2$ の 奥行値を比較し,

$\operatorname{depth}(\mathrm{p} 1)>\operatorname{depth}(\mathrm{p} 2)$,

(p 1，p 2 はそれぞれ領域 R 1，R 2 内の点

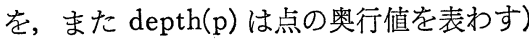
となる領域の面積之 R 1 の面積との比 $\sigma$ を求める.

$\sigma$ の值からオクルージョンの判定が得られる.すな わち， $\sigma=0$ は，オクルージョンなしを意味し，また， $\sigma=1.0$ は, 注視対象領域がすべて鿵されているオク ルージョンが生じているてとを意味している.

\section{3 オクルージョン空間の生成機能}

注視対象に仮想の点光源, 線光源, あるいは面光源 を置き, 環境内の他の物体に関して生じる影の空間 (shadow volume) ${ }^{14)}$ を求める. てれを『オクルージョ ン空間 (occlusion volume)』と呼ぶととにする. 前述 した OFS は，環境内の各物体によるオクルージョン 空間の和空間を，マニピュレータの作業空間から除い た補空間となる。

注視対象が 3 次元空間内の点の場合には，その点に 仮想点光源を置き，各物体に関して仮想の影空間すな わちオクルージョン空間を生成する. この処理は，以 下の手順で行う.

（1）注視点に仮想カメラを定義する.

（2）このカメラより見たオクルージョン物体のシル エット形状を求める.

（3） シルエットの多角形を底面とし, 注視点を頂点 とするような多角錐を生成する.

（4）乙の多角錐とロボット作業空間との積の立体を 求める.

また，注視対象が領域の場合には，同様な考え方で 仮想の面光源を置くことにより，オクルージョン空間 を求めることができる. 現在のハンドアイシミュレー タでは，前者の注視対象が点の場合についてのみ実現 しており，てれに関する実験を以下に述べる.

\section{4 実 験}

Fig. 4(a) 亿環境の物体の配置例を示す. 今, 注視 対象はバルブ上面の中心であると仮定する.オクルー ジョンを起す物体は，マニピュレータとバルブの間に あるパイプである．とのオクルージョン空間を求めた 例を, Fig. 4(b)，（c)に示す. Fig. 4(b)は，注視 点に置いた仮想カメラからみたパイプのシルエット領 域形状を底面とし，注視点を頂点としてオグルージョ ン空間を生成したものである．との例では角錐の高さ

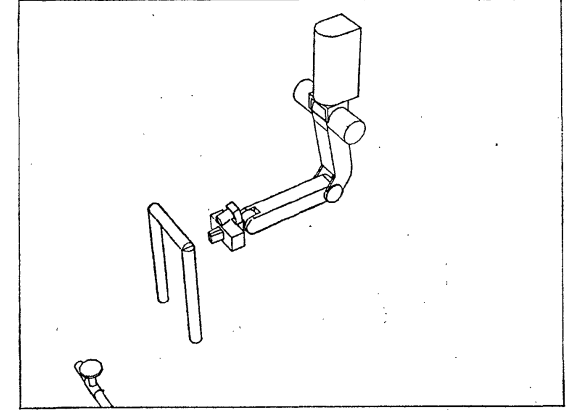

(a) An example of robot environment

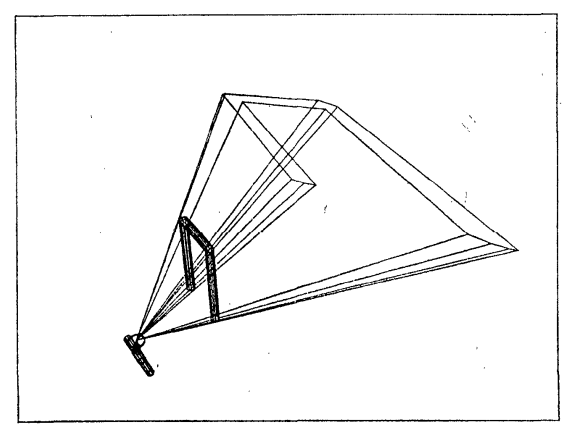

(b) An example of generated occlusion volume with hight of $1.5 \mathrm{~m}$

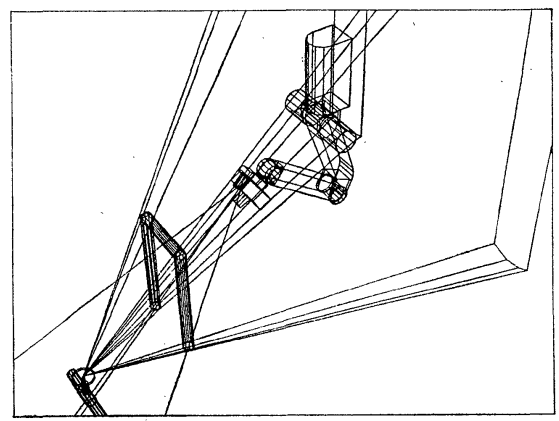

(c) An occlusion volume and a view volume of a camera-in-hand

Fig. 4 An example of generating occlusion volumes を $1.5 \mathrm{~m}$ として生成しているが，実際には作業空間と の交差を求めるので，ての高さを十分高くとって生成 する. Fig. 4(c)は，乙のようにして生成した多角錐 と， 1 辺が $4 \mathrm{~m}$ の立方体として与えた作業空間との交 差から求められたオクルージョン空間を示したあので ある. この図では，実際のカメラキャリブレーション により得られたハンド装着型カメラのパラメータに基 づいて，このカメラが捕える視野空間 (view volume) を四角錐体として同時に表示している.

OFS の記述に基づいて，実際に対象を撮像するの に適した空間点を決めるためにはママニピニレータの 
可動範囲や注視対象の状態に関する指定など，種々の 条件を考慮する必要がある．また，環境との衝突回避 を行うための自由空間記述系との結合などあ行う必要 があると考えられる.

\section{6. 結 論}

本論文では，ハンドアイシステムを対象として，そ のビジョン機能を支援するためのロボットシミュレー タの概念を提案し，実際のシステムについて開発した ハンドアイシミュレータの基本構成について述べた.

つぎに，ハンドアイシミュレータの特徽的機能とし て，視野内に現われるマニピュレータ像を消去する機 能，および，ハンド装着型のカメラなどが対象を撮像 する際に自動的にオクルージョンを回避するための支 援機能について述べ，視覚センサのためのシミュレー タシステムの有効性を明らかにした.

ロボットのセンサはロボット環境の不確定な要素を 取扱う目的で用いられるために，そのシミュレーショ ンは一般論として困難視されていた向きがある. しか しながら，ロボットの視覚のためのシミュレータに は，環境認識を信頼性良く効率的に行うための対象モ デルの供給を始め，本論文で指摘したようなセンサ系 の効果的運用を支援するためのシミュレーション等, 重要な課題が多数存在する.すなわち，ロボット環境 のモデルに基づき種々の拘束条件をシミュレーション で充分利用するととにより，より柔軟で適応性のある ロボットの視覚機能を実現するととが可能になると考 えられる.

マニピュレーションの教示においてティーチングか らロボット言語とシミュレータによるオフラインプロ グラミングへと発展したのと同様に，ロボット視覚セ ンサの利用についても，従来の現場での試行錯誤によ る方法から，センサシミュレーションを十分に利用し たモデルベーズドなオフラインプログラミングへ発展 させていく必要がある.

ハンドアイシミュレータをさらに拡張していくべき 今後の課題としては,

（1）認識対象物のモデル供給機能との結合

（2）オクルージョン回避行動の実現
（3） プラニングシステムとの結合 などがある。

最後に，当所，情報制御研究室・佐藤知正主任研究 官，システム制御研究室・末広尚士技官をはじめ，八 ンドアイシミュレータの作成にあたり御協力を頂いた 電総研ロボットグループの方々，また，本研究の機会 を与えて下さいました白井良明制御部長に深く感謝致 します.

\section{参 考 文 献}

1) T. Lozano-Pérez: Robot Programming, Proc. of IEEE, 71-7, 821/841 (1983)

2) 白井：モデルベーズドビジョン，日本ロボット学会誌, 2-6, 89/94 (1984)

3) Y. Baolin: Combining Vision Verification with a High Level Robot Porgramming Langurage, Ph. D. Thesis, Dept. of Artificial Intelligence, Univ. of Edinburgh (1984)

4) 松下: 3 次元物体の検出・測定を行うためのロボットビ ジョン言語, 日本ロボット学会誌，2-6，32/39 (1984)

5) R. W. Daniel and P. G. Davey: Two Key Problems in Robotics Research, Proc. ISRR '84, 273/278 (1984)

6) 画像処理 システム VIEW 小特集, 電総研粢報, 49-4, 45/86 (1985)

7）坂根, 松下, 石井, 佐藤, 柿倉：ハンドアイシステムの 基本構成, 電気学会システム・制御研究会資料, SC-8418 (1984)

8) M. Hosaka and F. Kimura: An Interactive Geometrical Design System with Hand-Writing Input, Information Processing 77, 167-172, North Holland, Amsterdam (1977)

9）小笠原：ロボット制御に要求される LISP の機能，電気 学会システム・制御研究会資料, SC-84-19 (1984)

10）末広，高瀬：構造的動作記述に基づくロボット用言語, 昭和 57 年電気学会全国大会講演会論文集，1630/1631 (1982)

11) D. G. Lowe: Solving for the Parameters of Object Models from Image Descriptions, Proc. of ARPA Image Understanding Workshop, 121/127, April (1980)

12) S. Ganapathy: Decomposition of Transformation Matrices for Robot Vision, Proc. IEEE Conf. on Robotics, 130-138 (1984)

13) T. Lozano-Pérez : Automatic Planning of Manipulator Transfer Movements, IEEE, Trans. SMC11-10, 681/698 (1981)

14) F.C. Crow: Shadow Algorithms for Computer Graphics, Computer Graphics, ACM Siggraph, 112, 242/248 (1977) 